\title{
Varietal performance of garden pea (Pisum sativum var. hortense) under Terai zone of West Bengal
}

\section{S. Datta*}

Regional Research Station, Terai Zone, Uttar Banga Krishi Viswavidyalaya, Pundibari, Cooch Behar-736165 (West Bengal), India

K. Das

Department of Vegetable and Spice Crops, Uttar Banga Krishi Viswavidyalaya, Pundibari, Cooch Behar-736165 (West Bengal), India

*Corresponding author. E-mail: suchanddatta@gmail.com

\begin{abstract}
The present study was conducted during the rabi season of the years of 2014-15 and 2015-16 at the Instructional Farm of Uttar Banga Krishi Vishwavidyalaya, Pundibari, Cooch Behar to evaluate the performance of twelve garden pea (Pisum sativum var. hortense) genotypes (Arkel, Azad P-1, Kohinoor-10, Nirali, PusaPragathi, PH 89, Sabuj Sona, Punjab 89, Azad P-3, Debratna-111, PAN 4009, Golden Pea Geetanjali) with respect to plant height $(\mathrm{cm})$, days to flowering (days), pod length $(\mathrm{cm})$, pod width $(\mathrm{cm} 0$, number of pods, yield(g/plant and tonnes/hectare), shelling per cent $(\%)$ and protein content (\%) in terai region of West Bengal. The experiment was carried out in factorial randomized block design with three replications. Farm yard manure (FYM) @ 15tonnes/ha was applied during land preparation and common fertilizer dose N:P:K @30:50:50 kg/ha was applied in each treatment. The results of the experiment revealed that the highest plant height $(51.57 \mathrm{~cm})$ and earliest flowering at 45.22 days after sowing (DAS) was obtained from Azad P-3 and Arkel respectively; whereas lowest plant height $(35.62 \mathrm{~cm})$ and most delayed flowering (53.61 DAS) were observed in Sabuj Sona. The higher magnitude of number of pods per plant(19.98), number of seeds per pod (7.27), yield per plant (69.34 g)and total yield per hectare $(12.33 \mathrm{t} / \mathrm{ha}$ ) were recorded in Kohinnoor-10.Regarding the quality parameters, Azad P-3 recorded the highest shelling percentage $(48.93 \%)$ as well as the highest protein percentage $(23.24 \%)$.Considering the yield parameters and yield Kohinnoor-10 may be selected; whereas with respect to quality parameters Azad P-3 may be superior for the terai region of West Bengal.
\end{abstract}

Keywords: Garden pea, Growth performance, Quality, Variety, Yield

\section{INTRODUCTION}

Garden pea (Pisum sativum var. hortense) is an important leguminous crop grown extensively throughout the world with production of 17,671 thousand tonnes in 2015. India is the largest producer of garden pea next to China (Avramenko, 2017). In India, it is grown mainly as a winter season vegetable in the plains of North India and as a summer season vegetable in the hills in other states. Fresh seed and pea pods can be used as a fresh vegetable or as a conserved, frozen product; dry seed as food; hay feed for animals and green fertilizer. (Bozoglu et al., 2007). In India area of pea is 546.9 thousand ha and 5451.6 thousand tonnes production with productivity 10.0 tones/hectare (NHB, 2017). Each $100 \mathrm{~g}$ edible portion of the green pea contains moisture $78 \mathrm{~g}$, protein $6.3 \mathrm{~g}$, carbohydrates $14.4 \mathrm{~g}$, energy 84 Kcal, calcium $26 \mathrm{mg}$, phosphorus $116 \mathrm{mg}$, iron 1.9

\section{Article Info}

DOI:10.31018/jans.v10i3.1859 Received: August 3, 2018

Revised: August 21, 2018 Accepted: August 23, 2018

\section{How to Cite}

Datta, S. and Das, K. (2018). Varietal performance of garden pea (Pisum sativum var. hortense) under Terai zone of West Bengal. Journal of Applied and Natural Science, 10(3): 1032 - 1036 mg and vitamin A 640 IU (Thamburaj, 2013).Pea cultivars are classified into different types. On the basis of seed pea cultivars are divided into two classes, i.e., smooth or wrinkle seeded types; on the basis of height cultivars are classified into three classes, i.e., bush, medium tall and tall types and according to maturity three classes are early, mid season and late cultivars. Garden pea is a cool weather crop and grows best at the optimum mean temperature of $10-18^{\circ} \mathrm{C}$ (Thumburaj,2013). Hot dry weather lowers the quality of pods produced due to conversion of sugars into starch and hemicellulose. Cultivation of garden pea after harvesting of Aman rice is beneficial for increasing the soil nutrient status especially for soil nitrogen. Productivity of the crop in the northern parts of the West Bengal is (6 t/ha) as compared to the national average (9.5 t/ha) (IIVR, 2011). Productivity of the crop may be increased by adoption of proper management practices and introduction of new 
Datta, S. and Das, K. / J. Appl. \& Nat. Sci. 10 (3): 1032 - 1036 (2018)

varieties having high yield potentiality. In North Bengal condition mainly Arkel variety of garden pea is grown. Replacement of the existing variety may be helpful for increasing the productivity of the crop. Keeping these views, the present study was undertaken to explore the performance of garden pea genotypes with respect to yield and quality characters under terai zone of West Bengal.

\section{MATERIALS AND METHODS}

Present investigation was conducted at the Instructional Farm of Uttar Banga Krishi Viswavidyalaya, Pundibari, Cooch Behar (26019' 86" N latitude and 890 23' 53"E longitude, at an elevation of 43 meter above the mean sea level), West Bengal, India during the winter seasons of 2014-15 and 2015-16. The soil of the experimental site is sandy loam in nature having a pH of 5.79 with $0.91 \%$ organic carbon (Rapid Titration Method by Walkley and Black, 1934),157.33 kg/ha available nitrogen (Modified Macro Kjeldahl Method by Jackson, 1973)), $29.42 \mathrm{~kg} / \mathrm{ha}$ available phosphorus (Bray's No. 1 Method by Jackson, 1973)) and $130.65 \mathrm{~kg} / \mathrm{ha}$ available potassium (Flame Photometer Method by Jackson, 1973)). This region comes under subtropical humid region with an average minimum temperature ranging from7to $8^{\circ} \mathrm{C}$ to and maximum of 24 to $33.2^{\circ} \mathrm{C}$ during the experimental period of Nov- March during 201415 and 2015-16. The experiment was laid out in randomized block design with three replications. Treatments consist of twelve garden pea genotypes namely Arkel, Azad P-1, Kohinoor-10, Nirali, PusaPragathi, PH 89, Sabuj Sona, Punjab 89, Azad P-3, Debratna-111, PAN 4009, Golden Pea Geetanjali. Garden pea seeds were sown in the field maintaining a spacing of $45 \mathrm{~cm} \times 15 \mathrm{~cm}$ with following of all standard packages of practices. Sowing was done middle of November of each year and harvesting was started from last week of February and was continued till March. FYM @ 15tonnes/ha was applied during land preparation and common fertilizer dose N:P:K @30:50:50 kg/ ha was applied in each treatment. Data was recorded for growth, yield attributing parameters and yield that include plant height, flowering, pod length, pod width, number of pods per plant, number of seeds per pod, fresh yield per plant, total yield and two quality parameters include shelling percentage and protein percentage of the seeds of garden pea.

Protein content of dry seeds was estimated by the procedure as suggested by Lowry, (1951) where blue colour developed by reduction of phospomolybic phosphotungstic component in folin ciocalteau reagent by the amino acids tyrosin and tryptophan present in the protein plus the colour developed by the biuret reaction of the protein with the alkaline cupric tartarate are measured. To 1.0 $\mathrm{ml}$ of supernatant from above is added $5.0 \mathrm{ml}$ of alkaline copper sulphate reagent and thoroughly mixed. Allowed to stand for ten minutes and then add $0.5 \mathrm{ml}$ of Folin's reagent. In order to develop colour this is kept standing for 30 minutes. This was followed by recording absorbance in spectrophotometer at $660 \mathrm{~nm}$ (Model number ; Systronics $-106)$, against a blank. The blank is prepared by taking $1.0 \mathrm{~mL}$ of $0.5 \mathrm{M} \mathrm{NaOH}$ in place of sample in cuvette. Bovine serum albumin is used to draw a standard curve and the amount of proteins in different samples was estimated.

The data was subjected to statistical analysis by the Analysis of Variance method (Gomez and Gomez, 1984) and the significance of different sources of variations was tested by Error Mean Square by Fisher and Snedecor's 'F' test at probability level 0.05 . For determination of critical difference at 5\% level of significance, Fisher and Yates' table was consulted for comparison of the different parameters among the different genotypes studied for this experiment.

\section{RESULTS AND DISCUSSION}

Growth and flowering characters: The pooled analysis of two years data (Table 1) clearly re-

Table 1. Growth and flowering characters of the different varieties of garden pea (Pisum sativum var. hortense).

\begin{tabular}{lcccccc}
\hline \multirow{2}{*}{ Variety } & \multicolumn{3}{c}{ Plant Height (cm) } & \multicolumn{3}{c}{ Days to flowering (days) } \\
\cline { 2 - 6 } & $\mathbf{2 0 1 4 - 1 5}$ & $\mathbf{2 0 1 5 - 1 6}$ & Pooled & $\mathbf{2 0 1 4 - 1 5}$ & $\mathbf{2 0 1 5 - 1 6}$ & Pooled \\
\hline Arkel & 38.37 & 42.33 & 40.35 & 45.33 & 45.11 & 45.22 \\
Azad P-1 & 51.93 & 50.07 & 51.00 & 50.00 & 49.67 & 49.83 \\
Kohinoor-10 & 45.77 & 52.07 & 48.92 & 53.33 & 53.44 & 53.39 \\
Nirali & 37.40 & 43.07 & 40.23 & 52.33 & 52.11 & 52.22 \\
PusaPragathi & 42.53 & 43.73 & 43.13 & 50.33 & 50.78 & 50.56 \\
PH 89 & 40.33 & 42.60 & 41.47 & 48.67 & 48.89 & 48.78 \\
Sabuj Sona & 33.97 & 37.27 & 35.62 & 53.67 & 53.56 & 53.61 \\
Punjab 89 & 36.70 & 39.53 & 38.12 & 51.33 & 51.44 & 51.39 \\
Azad P-3 & 50.90 & 52.23 & 51.57 & 55.67 & 56.22 & 55.94 \\
Debratna-111 & 38.40 & 43.13 & 40.77 & 47.67 & 48.22 & 47.94 \\
PAN 4009 & 44.53 & 48.13 & 46.33 & 53.00 & 53.33 & 53.17 \\
Golden Pea Geetanjali & 41.87 & 45.67 & 43.77 & 49.67 & 50.22 & 49.94 \\
SEm \pm & 1.57 & 1.52 & 1.09 & 0.77 & 0.65 & 0.51 \\
CD (P=0.05) & 4.61 & 4.45 & 3.10 & 2.27 & 1.91 & 1.44 \\
\hline
\end{tabular}


Datta, S. and Das, K. / J. Appl. \& Nat. Sci. 10 (3): 1032 - 1036 (2018)

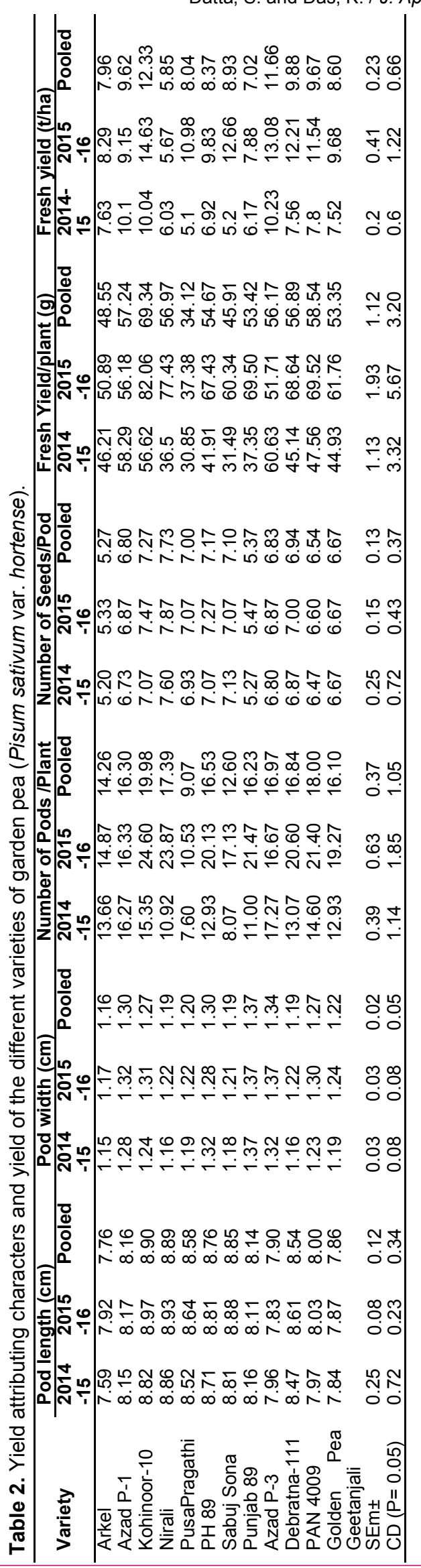

vealed that there is a significant variation regarding growth and flowering parameters among the different genotypes of garden pea under consideration. The variety Azad P-3 recorded the highest plant height $(51.57 \mathrm{~cm})$ followed by Azad P-1 $(51.00 \mathrm{~cm})$, Kohinoor-10 (48.92 cm) and PAN 4009 (46.33cm); whereas the lowest plant height was obtained from Sabuj Sona $(35.62 \mathrm{~cm})$. The variation in plant height may be ascribed to due to variation among the characters of the genotypes. as reported by Kumar et al., (2008), Singh and Singh (2011) and ) and Khan et al., (2013). Variation in duration of flowering was also reported in different genotypes. Earliest flowering was obtained from Arkel (45.22 DAS) followed by Debratna-111(47.94 DAS) and $\mathrm{PH}-89$ (48.78 DAS) and most delayed flowering was recorded in Sabuj Sona (53.61 DAS). Sharma (1999) reported that the variation in days to flowering may be attributed to the variation in the heat units and degree-days required by the particular cultivar. Agarwal et al. (2006) and Khan et al. (2013) also reported that there was a significant variation in days to flowering among the cultivars.

Yield attributing characters and yield: Average performance over two consecutive years recorded regarding fruiting attributes and yields (Table 2) clearly indicated that there is a little effect on pod length and pod width due to genetic variation. Among the twelve genotypes, Kohinoor-10 produced longest pod length $(8.90 \mathrm{~cm})$ followed by Nirali $(8.89 \mathrm{~cm})$, Sabuj Sona $(8.85 \mathrm{~cm})$ and $\mathrm{PH} 89$ $(8.76 \mathrm{~cm})$ which are also statistically at parwith Kohinoor-10 regarding pod length. Considering the pod width, highest data was obtained from Punjab $89(1.37 \mathrm{~cm})$ and it was lowest in Arkel $(1.16 \mathrm{~cm})$. The highest number of pods per plant (19.98)was recorded in Kohinoor-10 followed by PAN 4009 (18.00) and Nirali (17.39) and was lowest in PusaPragathi (9.07). The variation in number of pods per plant in different varieties was also supported by Khichi et al. (2016) and Kumar et al., (2008).Nirali recorded the highest number of seeds per pod(7.73) followed by Kohinoor-10 (7.27) and $\mathrm{PH}$ 89(7.17) which are statistically at par with respect to seeds per pod; whereas lowest number of seeds per pod (5.27) was recorded in Arkel. The results were also consensus with the findings of Amjad and Anjum (2002) and Khan et al., (2013)in pea with respect to different varieties. Significantly the highest yield per plant $(69.34 \mathrm{~g})$ and total yield (12.33 t/ha) were recorded in Kohinoor-10. Higher values of yield per plant was also obtained from PAN 4009 (58.54 g), Azad P-1 (57.24g), Nirali (56.97g), Debratna-111(56.89g) and Azad P-3 $(56.17 \mathrm{~g})$ which are statistically at par and higher yield was also recorded in Azad P-3 (11.66 t/ha) followed by Debratna-111 (9.88 t/ha),PAN 4009 (9.67 t/ha) and Azad P-1(9.62 t/ha). Debratna-111 (9.88 t/ha),PAN 4009 (9.67 t/ha) and Azad P-1 are statistically at parin terms of yield; whereas lowest 
Datta, S. and Das, K. / J. Appl. \& Nat. Sci. 10 (3): 1032 - 1036 (2018)

Table 3. Quality parameters of the different varieties of garden pea (Pisum sativum var. hortense )

\begin{tabular}{lllllll}
\hline \multirow{2}{*}{ Variety } & \multicolumn{3}{l}{ Shelling Per cent } & \multicolumn{3}{c}{ Protein Per cent (on dry weight basis) } \\
\cline { 2 - 6 } & $\mathbf{2 0 1 4 - 1 5}$ & $\mathbf{2 0 1 5 - 1 6}$ & Pooled & $\mathbf{2 0 1 4 - 1 5}$ & $\mathbf{2 0 1 5 - 1 6}$ & Pooled \\
\hline Arkel & 40.19 & 40.52 & 40.35 & 19.31 & 19.10 & 19.21 \\
Azad P-1 & 47.47 & 47.30 & 47.39 & 20.67 & 20.84 & 20.75 \\
Kohinoor-10 & 47.67 & 48.32 & 47.99 & 19.39 & 19.40 & 19.40 \\
Nirali & 48.74 & 48.37 & 48.55 & 18.97 & 19.12 & 19.05 \\
PusaPragathi & 45.12 & 45.72 & 45.42 & 22.08 & 22.09 & 22.08 \\
PH 89 & 44.64 & 44.00 & 44.32 & 19.98 & 19.86 & 19.92 \\
Sabuj Sona & 43.26 & 43.80 & 43.53 & 19.73 & 19.97 & 19.85 \\
Punjab 89 & 42.62 & 42.90 & 42.76 & 21.29 & 21.00 & 21.14 \\
Azad P-3 & 49.24 & 48.63 & 48.93 & 23.30 & 23.18 & 23.24 \\
Debratna-111 & 40.90 & 41.72 & 41.31 & 21.06 & 21.13 & 21.09 \\
\hline
\end{tabular}

yield per plant $(34.12 \mathrm{~g})$ and total fresh yield $(5.85$ t/ha) was obtained fromPusaPragathi and Nirali respectively. Yield is a complex character determined by the interaction of many heritable characters with soil, climate and agronomic conditions (Makasheva 1983).So, the variation in yield per plant and total yield of garden pea varieties observed in the present study may be due to their inherited traits and to some extent by environmental factors.Similar results have been also reported by Amjad and Anjum (2002), Khan et al., (2013) and Khichi et al., (2016),

Quality parameters: The pooled analysis of consecutive two years data in Table 3 clearly revealed that quality parameters like shelling percentage (\%) and protein percentage (\%)varied significantly in different varieties of pea. Azad P-3 recorded the highest shelling percentage $(48.93 \%)$ as well as the highest protein percentage $(23.24 \%)$. Higher shelling percentage was also obtained from Nirali $(48.55 \%)$, Kohinoor-10 (47.99\%) and Azad P-1 (47.39\%) which was statistically at par with Azad P-3 and it was lowest in Arkel (40.35\%). Kumar et al. (2008) reported that the high shelling percentage is an important criterion for economical production in pea. Chadha et al. (2013) observed that pod shelling percentage varied from 35.67 (DPP-54) to $66.17 \%$ (DPPMWR) in 2011-12 and 24.64 (FC-2) to $57.08 \%$ (IC296678) in 2012-13. In the present experiment, variation in the shelling percentage with respect to different variety was also noticed. Among the different genotypes, higher was recorded in Pusa Pragathi (22.08\%), Punjab 89 (21.14\%) and Debratna-111 (21.09\%) and lowest protein was obtained from Nirali (19.05\%). Variation in protein percentage of seeds among the different genotypes of garden pea was also reported by Phom et al. (2014).

\section{Conclusion}

The experimental findings revealed that garden pea genotypes Kohinoor-10 (12.33 t/ha) and Azad P-3 (11.66 t/ha) may be adopted for its commercial cultivation under terai region of West Bengal by considering the yield and quality.

\section{REFERENCES}

1. Agarwal, A., Gupta, S. and Ahmed, Z. (2006). Performance of garden pea (Pisum sativum) cultivars in high altitude cold desert of Ladakh. Indian journal of Agricultural Sciences, $76: 713-715$.

2. Amjad, M. and Anjum, M. A. (2002). Performance of nine pea cultivars under Faisalabad conditions. Pakistan Journal of Agricultural Sciences. 39: 16-19.

3. Avramenko, S. (2017) Which Country Produces the Most Green Peas in the World? Other Non-Perennial Crops, November 07, 2017, (https:/l www.indexbox.io/blog/which-country-produces-themost-green-peas-in-the-world/)

4. Bozoglu, H., Peksen, E., Peksen, A. and Gulumser, A. (2007). Determination of the yield performance and harvesting periods of fifteen pea (Pisum sativum L.) cultivars sown in autumn and spring. Pakistan Journal of Botany. 39: 2017-2025.

5. Gomez, K. A. and Gomez, A. A. (1984). Statistical Procedures for Agricultural Research (2 ed). Jhon Wiley and Sons .Newyork, 84-97.

6. IIVR (2011). Indian Institute of Vegetable Research Database. Indian Institute of Vegetable Research, Govt. of India., Varanasi, India.www.iivr.org.in.

7. Jackson, M. L. (1973). Soil Chemical Analysis. Prentice Hall of India Pvt. Ltd; New Delhi Delhi. pp 497.

8. Khan, T.N., Ramzan, A., Jillani, G. and Mehmood, T. (2013). Morphological performance of peas (pisum sativum L.) genotypes under rainfed conditions of potowar region. Journal of Agricultural Research, $51: 51-60$.

9. Khichi, P., Chandan, P. M., Chauhan, J., Srinivas, J. and Bhagat, M. (2016). Varietal evaluation of garden pea under semi-arid conditions of Vidharba region. International Journal of Farm Sciences, 6: 20-24.

10.Kumar, A. V. R., Sharma, R. R. and Deshmukh, P. S. (2008). Patterns of pod and seed growth during fruit development in garden pea genotypes. Indian Journal of Horticulture, 65: 293-296.

11.Lowry, O.H., Rosebrough, N.J., Farr, A.L. and Randall, R.J. (1951). Journal of Biological Chemistry, $193: 265-275$.

12.Makasheva, R. K. (1983). The pea. Oxonian Press Private Limited., New Delhi, India.,78 -107.

13.NHB., (2017). National Horticulture Database. National Horticulture Board, Govt. of India., Gurgaon, India.www.nhb.gov.in.

14.Phom, A. C., Kanaujia, S. P. and Chaturvedi, H. P. (2014). Performance of various genotypes of pea under foothill condition of Nagaland. Annals of Plant and Soil Research,16:285-288.

15.Sharma, T. R. (1999). Combining ability and hetero- 
Datta, S. and Das, K. / J. Appl. \& Nat. Sci. 10 (3): 1032 - 1036 (2018)

sis in garden pea (Pisum sativum) in the cold desert Himalayan region. Indian journal of Agricultural Sciences, 69 (5): 386-388.

16.Singh, R. and Singh, P.M. (2011). Effect of sowing dates and varieties on yield and quality of garden pea seed. Vegetable Science.,38:184-187.

17. Thamburaj, S. and Singh, N.(2013).Vegetables, Tu- bercrops and Spices. Directorate of Knowledge Management in Agriculture., Indian Agricultural Research Institute, New Delhi , India., 4-198.

18.Walkley, A. and Black, J. A. (1934). An estimation of the Degtjareff method for determining soil organic matter and proposed modification of the chronic acid titration methods. Soil Science, 37: 27-28. 